\title{
DAKWAH MODERASI DI TENGAH PANDEMI COVID 19
}

\author{
Muhamad Bisri Mustofa, Siti Wuryan \\ IAI Agus Salim Metro, UIN Raden Intan Lampung \\ Jl. Brigjend Sutiyoso, No. 7 Kota Metro, 34111 \\ muhamadbisrimustopa@iai-agussalimmetro.ac.id, siti@radenintan.ac.id
}

\begin{abstract}
Moderation is an effort to give someone freedom in expressing all aspects of their lives, by promoting the foundation of tolerance, unity, togetherness, diversity, sincerity, honesty, and middle ground (wasathiyah). Da'wah in its context has a close relationship with moderation, because in $D a^{\prime}$ wah also known as the 3 methods of $D a^{\prime}$ wah approach namely: bil hikmah, mauidzoh hasanah, and mujadalah. Bil wisdom (wise) puts forward wise things, can put things with full justice this principle in line with moderation. Then mauidzoh hasanah (in a better way), every behavior takes precedence through a better way, and finally is mujadalah (discussing) this indicates that everything needs to be found a way out by prioritizing deliberation and musfakat, especially in carrying out preaching. Apart from all aspects of the da'wah method and substance of moderation, the covid 19 pandemic caused a new chapter in the da'wah moderation, by carrying out physical distancing, clean living, and wearing masks. Da'wah moderation is implemented through online technology (in the network) that can access all the mad'u through applications such as Zoom Cloud Meeting, Google Meeting, Webbex, Skype, and others.
\end{abstract}

Keywords : Da'wah, Moderation, Pandemic, Covid 19

\begin{abstract}
Abstrak
Moderasi merupakan upaya untuk memberikan keleluasaan kepada seseorang dalam mengekspresikan seluruh aspek kehidupannya, dengan mengedepankan landasan toleransi, persatuan, kebersamaan, keberagaman, ketulusan, kejujuran, dan jalan tengah (wasathiyah). Dakwah dalam konteks nya memiliki kaitan erat dengan moderasi, karena dalam dakwah juga dikenal dengan 3 metode pendekatan dakwah yaitu : bil hikmah, mauidzoh hasanah, dan mujadalah. Bil hikmah (bijaksana) mengedepankan hal-hal yang arif, dapat menempatkan sesuatu dengan penuh keadilan prinsip ini sejalan dengan moderasi. Lalu mauidzoh hasanah (dengan cara yang lebih baik), setiap tingkah laku didahulukan melalui cara yang lebih baik, dan terakhir adalah mujadalah (berdiskusi) hal ini menandakan segala sesuatu perlu di cari jalan keluar dengan mengedepankan musyawarah dan musfakat terutama dalam melaksanakan dakwah. Terlepas dari semua aspek metode dakwah dan substansi moderasi, pandemi covid 19 menyebabkan babak baru dalam dakwah moderasi, dengan dilaksanakannya physical distancing, hidup bersih, dan menggunakan masker. Dakwah moderasi di implementasi melalui teknologi daring (dalam jaringan) yang dapat mengakses seluruh mad'u melalui aplikasi seperti Zoom Cloud Meeting, Google Meeting, Webbex, Skype, dan lain-lain.
\end{abstract}

\section{Kata Kunci : Dakwah, Moderasi, Pandemi, Covid 19}

How to Cite :

MB, Mustofa, S. Wuryan (2020). Dakwah Moderasi di Tengah Pandemi Covid 19. Mau'idhoh Hasanah: Jurnal Dakwah dan Ilmu Komunikasi, 2 (1), 1-10. 


\section{Pendahuluan}

Dakwah dan Moderasi merupakan hal yang berkesinambungan, dimana dalam prinsip-prinsip dakwah juga mengenal adanya al adl (adil) yaitu menyampaikan kebaikan dengan menyesuaikan kepada mad'u (pendengar), saat ini pemerintah telah melarang adanya kerumunan massa dalam jumlah banyak, maka adil dalam hal ini para da'i masih dapat melaksanakan tugas nya melalui media social atau secara daring. Prinsip kedua adalah al tasamuh (toleransi) hal ini menunjukan bahwa dakwah tidak hanya kepada orang Islam saja, namun dakwah juga dapat dilakukan dengan seluruh masyarakat dengan membawa nilai-nilai ketuhanan dan kesahajaan. Ketiga adalah prinsip al tawazun (keseimbangan) dakwah yaitu mengajak kepada keselarasan dan keserasian dalam menyampaikan pesan-pesan dakwah, menghindari diskriminatif dan ekslusifitas. Keempat al taharum (kasih sayang), dakwah ditunjukan dengan sifat yang rahmah cinta kepada seluruh ummat sebagaimana mencintai diri sendiri.

Keempat prinsip diatas merupakan landasan penting bagi seorang da'i untuk dapat diterima ditengah kemajemukan masyarakat Indonesia, yang berbeda-beda bahasa, suku, ras dan budaya. Seorang da'i tidak hanya mengajak untuk kebaikan namun juga mengajak untuk saling menebarkan keserasian, keselarasan, kebersatuan, dan keseimbangan prilaku sosial beragama. Dakwah moderasi bukanlah hal yang baru untuk di gaungkan saat pandemi Covid 19 melanda seluruh Negara di Bumi, tetapi dakwah ini telah berlangsung lama bahkan sejak risalah dakwah ini masih di emban oleh para Nabi dan Rasul.

Dakwah moderasi yang saat ini dapat dilakukan dan telah dilaksanakan juga oleh bebagai kalangan dan organisasi keagamaan adalah dengan melalui media daring atau dakwah online, dengan berbagai cara, diantaranya Webinar, Halal bi Halal Virtual, Kajian Keagamaan Virtual, yang dilakukan oleh para mubaligh dan penceramah untuk tetap dapat menyapa mad'u nya yang diharuskan berada dirumah. Hal ini selaras dengan anjuran yang disampaikan oleh pemerintah untuk senantiasa berada dirumah, dan menjaga pola hidup sehat.

\section{Pembahasan}

\section{A. Dakwah}

Ditinjau dari sudut etimologi atau bahasa, dakwah berasal dari bahasa Arab, yang berarti panggilan, ajakan, atau seruan. Menurut ilmu tata bahasa Arab, kata dakwah berbentuk "isim masdar" yang berasal dari fiil (kata kerja) "da"a" ( دعاد) "yad"u" (د دعوة ) (د دعو ) yang artinya memanggil, mengajak, atau menyeru. ${ }^{1}$

Sedangkan menurut Toha Yahya Umar, M.A. dalam bukunya Ilmu Dakwah mendefinisikan dakwah adalah mengajak manusia dengan cara bijaksana kepada jalan yang benar sesuai dengan perintah Tuhan untuk keselamatan dan kebahasiaan mereka di dunia dan akhirat. ${ }^{2}$ Dakwah secara subtansi merupakan sarana seseorang untuk mendekatkan diri kepada Pencitptanya. Metode dakwah menjadi sarana yang terbaik untuk mendekatkan seseorang dalam menyampaikan risalah ketuhanan. Dengan adanya metode dakwah yang sesuai

1 Saputra, Pengantar Ilmu Dakwah, (Jakarta: PT Raja Grafindo Persada, 2011), hlm. 1.

2 Samsul Munir Amin, Ilmu Dakwah, (Jakarta: Hamzah, 2009), hlm. 3 
dengan tipologi masyarakat akan memudahkan seorang Da'i dalam menyampaikan dakwahnya, agar terhindar dari problematika moderasi dakwah, seperti perbedaan faham, dan ekslusifitas dakwah.

\section{B. Metode Dakwah}

Dari segi bahasa metode berasal dari dua kata yaitu "meta" (melalui) dan "hodos" (jalan, cara). Metode adalah cara atau jalan yang harus dilalui untuk mencapai suatu tujuan. Sumber yang lain menyebutkan bahwa metode berasal dari bahasa Jerman methodica, artinya ajaran tentang metode. Dalam bahasa Yunani metode berasal dari kata methodos artinya jalan yang dalam bahasa Arab disebut thariq. ${ }^{3}$ Ada beberapa metode dakwah dalam Al Qur'an Surat An Nahl : 125 : hikmah, pelajaran yang baik dan mujadalah. Hal tersebut dapat diambil pemahaman bahwa metode dakwah itu meliputi tiga cakupan. Moh. Ali Aziz dalam bukunya Ilmu Dakwah secara garis besar tiga cakupan metode dakwah, yaitu:4

\section{Bil Hikmah}

Berdakwah dengan memperhatikan situasi dan kondisi sasaran dakwah dengan menitikberatkan pada kemampuan-kemampuan mereka, sehingga di dalam menjalankan ajaran-ajaran Islam selanjutnya, mereka tidak lagi merasa terpaksa atau keberatan. Sebagai metode dakwah, hikmah diartikan bijaksana, akal budi yang mulia, dada yang lapang, hati yang bersih, dan menarik perhatian orang kepada agama dan Tuhan.

Menurut Imam Abdullah bin Ahmad Mahmud An-Nasafi dalam buku Metode Dakwah karya M. Munir, mengartikan hikmah, yaitu: "Dakwah bilhikmah" adalah dakwah dengan menggunakan perkataan yang benar dan pasti, yaitu dalil yang menjelaskan kebenaran dan menghilangkan keraguan.

Dari pengertian tersebut, M. Munir mengartikan hikmah merupakan kemampuan dan ketepatan $d a^{\prime} i$ dalam memilih, memilah dan menyelaraskan teknik dakwah dengan kondisi objektif mad'u. ${ }^{5}$

2. Mauizhaah Hasanah

Terminologi mauizhaah hasanah dalam perspektif dakwah sangat populer. Istilah mauizhaah hasanah terdiri dari dua kata, mauizhaah dan hasanah. Kata mauizhaah berarti nasihat, bimbingan, pendidikan dan peringatan, sementara hasanah merupakan kebalikan dari sayyi'ah yang artinya kebaikan lawan kejelekan. Mauizhaah hasanah yaitu berdakwah dengan memberikan nasihatnasihat atau menyampaikan ajaran-ajaran Islam yang disampaikan itu dapat menyentuh hati mereka. ${ }^{6}$

Menurut Imam Abdullah bin Ahmad Mahmud An-Nasafi dalam buku Metode Dakwah karya M. Munir, mengartikan Mauizhaah Hasanah, yaitu: "alMauizhaah al-Hasanah" adalah (perkataan-perkataan) yang tidak tersembunyi bagi mereka, bahwa engkau memberikan nasehat dan menghendaki manfaat kepada mereka atau dengan al-Qur'an.

\footnotetext{
${ }^{3}$ M. Munir, Metode Dakwah, Cet. Ke-3, (Jakarta: Kencana, 2009), hlm. 7.

${ }^{4}$ Aziz, Moh. Ali, Ilmu Dakwah Edisi Revisi, (Jakarta: Kencana, 2004), hlm. 136

${ }^{5}$ M. Munir, Metode Dakwah, Op.Cit, hlm. 10-11

${ }^{6}$ Aziz, Moh. Ali, Ilmu Dakwah Edisi Revisi, Op.Cit, hlm. 136
} 
Sedangkan menurut M. Munir sendiri, pengertian dari Mauizhaah Hasanah adalah kata-kata yang masuk ke dalam perasaan dengan penuh kelembutan, tidak membongkar atau membeberkan kesalahan orang lain, sebab kelemah-lembutan dalam menasehati seringkali dapat meluluhkan hati yang keras dan menjinakkan qalbu yang liar.

3. Mujadalah

Mujadalah adalah berdakwah dengan cara bertukar pikiran dan membantah dengan cara yang sebaik-baiknya dengan tidak memberikan tekanan-tekanan kepada sasaran dakwah. ${ }^{7}$ Menurut Imam Abdullah bin Ahmad Mahmud An-Nasafi dalam buku Metode Dakwah karya M. Munir, mengartikan Mauizhaah Hasanah, yaitu:

"Berbantahan yang baik yaitu dengan jalan yang sebaik-baiknya dalam bermujadalah, antara lain dengan perkataan yang lunak, lemah lembut, tidak dengan ucapan yang kasar atau dengan mempergunakan sesuatu (perkataan) yang bisa menyadarkan hati, membangunkan jiwa dan menerangi akal pikiran, ini merupakan penolakan bagi orang yang enggan melakukan perdebatan dalam agama.

Dari pengertian tersebut, M. Munir mengartikan mujadalah merupakan tukar pendapat yang dilakukan oleh dua pihak secara sinergis, yang tidak melahirkan permusuhan dengan tujuan agar lawan menerima pendapat yang diajukan dengan memberikan argumentasi dan bukti yang kuat. ${ }^{8}$

\section{Dakwah Moderasi}

Sebelum memahami dakwah moderasi pertama-tama kita harus memaami substansi moderasi. Dalam Buku Moderasi Beragama ditulis oleh Kementerian Agama Republik Indonesia, moderasi berasal dari Bahasa Latin moderâtio, yang berarti ke-sedangan (tidak kelebihan dan tidak kekurangan). Kata itu juga berarti penguasaan diri (dari sikap sangat kelebihan dan kekurangan). ${ }^{9}$

Kamus Besar Bahasa Indonesia (KBBI) menyediakan dua pengertian kata moderasi, yakni: 1. n pengurangan kekerasan, dan 2. $\mathrm{n}$ penghindaran keekstreman. Jika dikatakan, "orang itu bersikap moderat", kalimat itu berarti bahwa orang itu bersikap wajar, biasa-biasa saja, dan tidak ekstrem. Dalam bahasa Inggris, kata moderation sering digunakan dalam pengertian average (ratarata), core (inti), standard (baku), atau non-aligned (tidak berpihak). Secara umum, moderat berarti mengedepankan keseimbangan dalam hal keyakinan, moral, dan watak, baik ketika memperlakukan orang lain sebagai individu, maupun ketika berhadapan dengan institusi negara. 10

Sedangkan dalam bahasa Arab, moderasi dikenal dengan kata wasath atau wasathiyah, yang memiliki padanan makna dengan kata tawassuth (tengahtengah), i'tidal (adil), dan tawazun (berimbang). Orang yang menerapkan prinsip wasathiyah bisa disebut wasith. Dalam bahasa Arab pula, kata wasathiyah diartikan sebagai "pilihan terbaik". Apa pun kata yang dipakai, semuanya menyiratkan satu makna yang sama, yakni adil, yang dalam konteks ini berarti memilih posisi jalan tengah di antara berbagai pilihan ekstrem. Kata wasith bahkan sudah

${ }^{7}$ Ibid., hlm. 136

${ }^{8}$ M. Munir, Metode Dakwah, Op.Cit, hlm. 19

9 Kementerian Agama, Moderasi Beragama, (Jakarta : Kementerian Agama RI, 2019), hlm. 15

${ }^{10}$ Kementerian Agama, Moderasi Beragama, Ibid., hlm. 16 
diserap ke dalam bahasa Indonesia menjadi kata 'wasit' yang memiliki tiga pengertian, yaitu: 1) penengah, perantara (misalnya dalam perdagangan, bisnis); 2) pelerai (pemisah, pendamai) antara yang berselisih; dan 3) pemimpin di pertandingan. ${ }^{11}$

Dakwah moderasi pada hakikatnya dakwah yang mengedepankan sikap yang komunikatif, isi pesan dakwah dan metode yang di sampaikan menggunakan komunikasi dakwah dalam Al-Qur'an seperti Qoulan Baligha, Qulan Layyina, Qoulan Ma'rufa, Qoulan Maisura, Qoulan Karima, Qoulan Sadida. Dakwah Moderasi dimulai dari penyampaian pesan dakwah atau materi dakwah dengan mengedepankan perkataan yang jelas, lemah lembut, baik, mudah difahami, kasih sayang, dan terakhir adalah perkataan yang benar. Ini merupakan salah satu landasan dalam dakwah moderasi karena hal ini penting diperhatikan oleh seorang da'i agar menghindari konflik dalam dakwah dan meminimalisir sikap eksklusif tetapi inklusif.

1. Qaulan Balighan

Dalam bahasa arab kata Baligha diartikan sebagai "sampai", "mengenai sasaran", atau "sampai tujuan". Jika dikaitkan dengan kata-kata qawl (ucapan atau komunikasi) baligha berarti "fasih", "jelas maknanya", "tepat mengungkapkan apa yang dikehendaki" dan "terang". Akan tetapi, juga ada yang mengartikan sebagai "perkataan yang membekas di jiwa".12 Ungkapan qaulan balighan terdapat surat An-Nisa Ayat 63, yaitu :

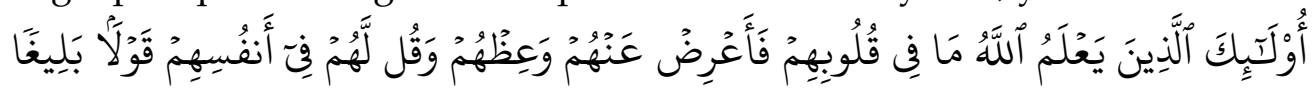

Artinya: Mereka itu adalah orang-orang yang Allah mengetahui apa yang di dalam hati mereka. Karena itu berpalinglah kamu dari mereka, dan berikanlah mereka pelajaran, dan katakanlah kepada mereka perkataan yang berbekas pada jiwa mereka.13

Yang dimaksud ayat diatas adalah perilaku orang munafik. Ketika diajak untuk memahami hukum Allah, mereka menghalangi orang lain untuk patuh. Kalau mereka mendapat musibah atau kecelakaan karena perbuatan mereka sendiri, mereka datang memohon perlindungan atau bantuan. Mereka inilah yang perlu dihindari, diberi pelajaran, atau diberi penjelasan dengan cara yang berbekas atau ungkapan yang mengesankan. Karena itu, qaulan baligha dapat diterjemahkan kedalam komunikasi efektif. ${ }^{14}$

Komunikasi yang efektif dalam dakwah, menurut Achmad mubarok apabila dilihat dari sudut psikologi dakwah, maka dakwah yang efektif memiliki Lima ciri yaitu: 15

a. Jika dakwah dapat memberikan pengertian kepada masyarakat (mad'u) tentang apa yang didakwahkan

b. Jika masyarakat (mad'u) merasa terhibur oleh dakwah yang diterima

c. Jika dakwah berhasil meningkatkan hubungan baik antara da'i dan masyrakat mad'u.

\footnotetext{
11 Kementerian Agama, Moderasi Beragama, Ibid., hlm. 16

12 Wahyu Ilahi, MA. Komunikasi Dakwah, (Bandung: PT.Remaja Rosdakarya,2010) hlm. 172

13 Departemen Agama RI, Al-Qur'an dan Terjemahnya, (Kudus: Menara Kudus, 2006), hlm. 88

14 M. Munir, S.Ag, MA. Metode Dakwah, (Jakarta:Kencana Prenada Media Group,2009), hlm. 
d. Jika dakwah dapat mengubah masyarakat mad'u.

e. Jika dakwah berhasil memancing respons masyarakat berupa tindakan.

Jalaludin Rahmat merinci pengertian qaulan baligha tersebut menjadi dua, Satu, qaulan baligha terjadi bila da'i (komunikator) menyesuaikan pembicaraannya dengan sifat-sifat khalayak yang dihadapinya sesuai dengan Frame of field of experience (kerangka pengalaman). Kedua, qaulan baligha terjadi bila komunikator menyentuh khalayaknya pada hati dan otaknya sekaligus. ${ }^{16}$

Dari paparan diatas, komunikasi dakwah dalam bentuk qaulan baligha adalah hendaknya para da'i harus seimbang dalam melakukan sentuhan terhadap mad'u, yaitu antara otaknya dan hatinya. Jika kedua komponen tersebut dapat terakomodasi dengan baik maka akan menghasilkan umat yang kuat, karena terjadi penyatuan antara hati dan pikiran. Interaksi aktif keduanya merupakan sebuah kekuatan yang kuat dan saling berkaitan dalam membentuk komunikasi yang efektif. Apabila salah satu ditinggalkan, maka akan terjadi ketimpangan dalam berkomunikasi.

2. Qaulan Layyinan

Layyina secara terminologi diartikan sebagai "lembut". Qaulan layyinan juga berarti perktaan yang lemah lembut. Perkataan yang lemah lembut dalam komunikasi dakwah merupakan interaksi komunikasi da'i dalam mempengaruhi mad'u untuk mencapai hikmah.17 Qaulan layyinan terlukis dalam Al-Qur'an Surat At-Thaha ayat 43-44.

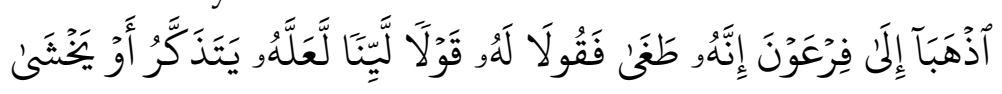

Artinya:

"Pergilah kamu berdua pada Fir'aun, sesungguhnya dia telah melampaui batas, maka berbicaralah kamu berdua kepadanyta dengan kata-kata yang lemah lembut. Mudah-mudahan ia ingat atau takut",18

Berkata lembut tersebut adalah perintah Allah kepada Nabi Musa dan Harun as, supaya menyampaikan Tabsyier dan Inzar kepada fir'aun dengan "qaulan layyinan" karena ia telah menjalani kekuasaan melampaui batas, Musa dan Harun as, sedikit khawatir menemui Fir'aun yang kejam. Akan tetapi, Allah tahu dan memberi jaminan.

Surat At-thaha ayat 46

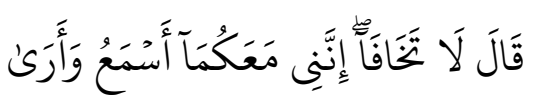

Artinya: Allah berfirman: "Janganlah kamu berdua khawatir, sesungguhnya Aku beserta kamu berdua, Aku mendengar dan melihat.

Berhadapan dengan penguasa yang tiran, Al-Qur'an mengajarkan agar dakwah kepada mereka haruslah bersifat sejuk dan lemah lembut, tidak kasar dan lantang perkataan kepada penguasa tiran dapat memancing respon yang lebih keras dalam waktu spontan, sehingga menghilangkan peluang untuk

\footnotetext{
16 Jalaluddin Rahmat, Islam Aktual, (Mizan,1996), hlm.83

17 Wahyu Ilahi, MA. Komunikasi Dakwah, Ibid, hlm. 178

${ }^{18}$ Departemen Agama RI, Al-Qur'an dan Terjemahnya, (Kudus: Menara Kudus, 2006), hlm. 314
} 
berdialog atau berkomunikasi antar kedua belah pihak, da'i dan penguasa $\operatorname{mad}^{\prime} u{ }^{19}$

Dengan demikian, interaksi aktif dari qaulan layyina adalah komunikasi yang ditunjukan pada dua karakter mad'u. Pertama, adalah pada mad'u tingkat penguasa dengan perkataan yang lemah lembut menghindarkan atau menimbulkan sikap konfrontatif. Kedua, mad'u pada tataran budayanya yang masih rendah. Sikap dengan qaulan layyinan akan berimbas pada sikap simpati dan sebaliknya akan mengindarkan atau menimbulkan sikap antipati.20

3. Qaulan Ma'rufan

Ungkapan qaulan ma'rufan, jika ditelusuri lebih dalam dapat diartikan dengan "ungkapan atau ucapan yang pantas dan baik". "pantas" disini juga dapat diartikan sebagai kata-kata yang "terhormat", sedangkan "baik" diartikan sebagai kata-kata yang "sopan". ${ }^{21}$

Jalaluddin Rahmat mengartikan bahwa qaulan ma'rufan adalah pembicaraan yang bermanfaat, memberikan pengetahuan, mencerahkan pemikiran, menunjukkan pemecahan terhadap kesulitan orang yang lemah, jika kita tidak membantu secara materil, kita harus membantu mereka secara psikologi. Ungkapan qaulan ma'rufan dalam Al-Qur'an terungkap dalam ayat Al-Baqarah ayat 235, yaitu :

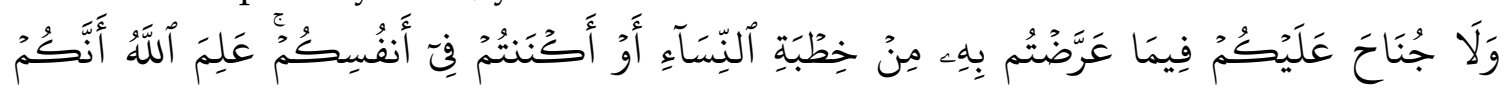

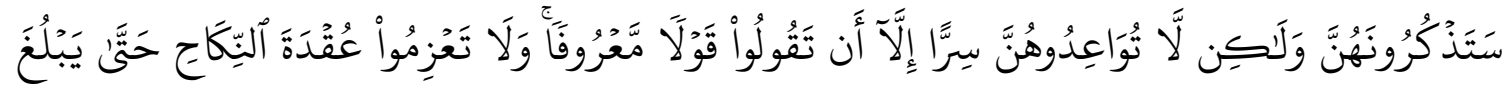

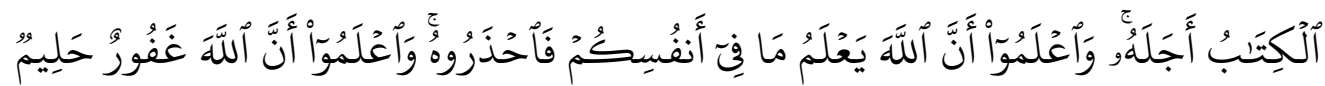

Artinya; "Dan tidak ada dosa bagi kamu meminang wanita-wanita itu dengan sindiran atau kamu menyembunyikan (keinginan mengawini mereka) dalam hatimu. Allah menegtahui bahwa kamu akan menyebut-nyebut mereka, dalam pada itu janganlah kamu mengadakan janji kawin dengan mereka secara rahasia, kecuali sekedar mengucapkan (kepada mereka) perkataan yang ma'ruf. Dan janganlah kamu ber'azam (bertetap hati) untuk bertekad nikah, sebelum habis 'iddahnya. Dan ketahuilah bahwasanya Allah mengetahui apa yang ada dalam hatimu; maka takutlah kepada-Nya dan ketahuilah bahwa Allah Maha Pengampun lagi Maha Penyantun". 22

Ayat tersebut, secara mutlak melarang pria mengucapkan sesuatu kepada wanita-wanita yang sedang menjalani masa 'iddah, tetapi kalau ingin mengucapkannya, ucapkan dengan kata-kata yang ma'ruf, sopan, serta terhormat, sesuai dengan tuntunan agama, yakni dengan sindiran yang baik. ${ }^{23}$

Dalam surat Al-Ahzab ayat 32 yaitu :

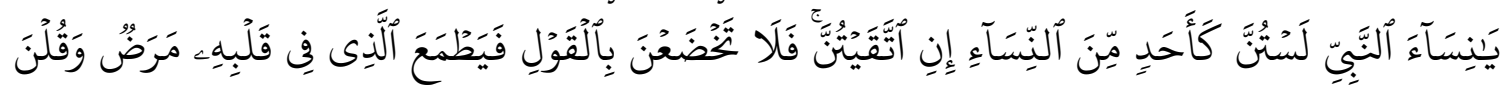

${ }_{19}$ M. Munir, S.Ag, MA. Metode Dakwah, (Jakarta:Kencana Prenada Media Group,2009), hlm.

20 Wahyu Ilahi, MA. Komunikasi Dakwah, Ibid, hlm.181

${ }^{21}$ Wahyu Ilahi, MA. Komunikasi Dakwah, Ibid, hlm.183

22 Departemen Agama RI, Al-Qur'an dan Terjemahnya, (Kudus: Menara Kudus, 2006), hlm. 422

${ }^{23}$ Wahyu Ilahi, MA.Komunikasi Dakwah, Opcit, hlm.185 
Artinya: "hai istri-istri Nabi, kamu sekalian tidaklah seperti wanita lain, jika kamu bertakwa. Maka janganlah kamu tunduk ketika berbicara sehingga berkeinginanlah orang yang ada penyakit dalam hatinya, dan ucapkanlah perkataan yang baik".

Pada ayat diatas qaulan ma'rufan berarti tuntunan kepada istri Rasul agar berbicara yang wajar-wajar saja tidak perlu bermanjamanja, tersipu-sipu, cengeng, atau sikap berlebihan yang akan mengundang nafsu birahi lelaki lawan bicara. Jika ditelusuri pada penafsiran kata sebelumnya, dalam ayat diatas yaitu "takda'na" terambil dari kata kudhu" yang pada mulanya berarti "tunduk".Kat ini apabila dikaitkan dengan ucapan, maka yang dimaksud adalah kerendahan suara. Wanita yang memiliki suara lemah lembut. Atas dasar itu, maka larangan berkata lemah lembut harus dipahami dalam arti membuatbuat suara yang lebih lembut lagi melebihi kodrat dan kebiasaannya berbicara. Cara berbicara demikian, biasa dipahami sebagai menampakkan kemanjaan pada lawan bicara yang pada gilirannya dapat menimbulkan hal-hal yang tidak direstui oleh agama. Larangan tersebut tertuju pada mereka jika berbicara kepada yang bukan muhrimnya. Adapun berbicara secara lemah lembut dihadapan suami atau anak pada dasarnya tidak dilarang.

Dalam konteks ayat tersebut, al-biqa'I memberikan kesan sebagai isyarat bahwa istri-istri Nabi Saw. Diperintahkan untuk berusaha sedapat mungkin melakukan lawan kelemahlembutan tersebut. ${ }^{24}$ Jalaluddin Rahmat menjelaskan bahwa qaulan ma'rufan adalah perkataan yang baik. Allah menggunakan frase ini ketika berbicara tentang kewajiban orang-orang kaya atau orang kuat terhadap orang-orang yang miskin atau lemah. Qaulan ma'rufan berarti pembicaraan yang bermanfaat, memberi pengetahuan, mencerahkan pemikiran, menunjukkan pemecahan terhadap kesulitan kepada orang lemah, jika kita dapat membantu secara material, kita harus dapat membantu psikologi. 25

4. Qaulan Maisura

Secara terminologi qaulan maisura berarti "mudah". Lebih lanjut dalam komunikasi dakwah dengan menggunakan qaulan maisura dapat diartikan dalam menyampaikan pesan dakwah, da'I harus menggunakan bahasa yang "ringan", "sederhana", "pantes" atau yang "mudah diterima" oleh mad'u secara spontan tanpa harus melalui pemikiran yang berat. ${ }^{26}$ Dalam Al-Qur'an kata-kata qaulan maisura terkandung dalam surat Al-Isra ayat 28 yaitu :

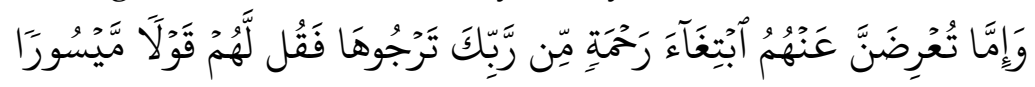

Artinya : "Dan jika kamu berpaling dari mereka untuk memperoleh rahmat dari Tuhanmu yang kamu harapkan, maka katakanlah kepada mereka ucapan yang pantas". ${ }^{27}$

Jika dikaji dari penafsiran sebagian ulama' berpendapat bahwa ayat tersebut turun ketika Nabi Muhammad Saw, menghindari dari orang yang minta bantuan karena merasa malu tidak dapat memberinya. Allah Swt, memberikan tuntunan yang lebih baik melalui ayat ini yakni menghadapinya dengan menyampaikan katakata yang lebih baik serta harapan memenuhi keinginan meminta di masa yang akan datang. Sedangkan, jika terkait dengan kalimat

\footnotetext{
${ }^{24}$ Wahyu Ilahi, MA. Komunikasi Dakwah, Ibid, hlm.186

${ }^{25}$ Jalaluddin Rahmat, Etika Komunikasi Prespektif Religi, (Makalah seminar: Jakarta, 1996)

${ }^{26}$ Wahyu Ilahi, MA. Komunikasi Dakwah, Op.cit, hlm.181

${ }^{27}$ Departemen Agama RI, Al-Qur'an dan Terjemahnya, (Kudus: Menara Kudus, 2006), hlm. 83
} 
"untuk memperoleh rahmat dari Tuhanmu" bisa juga dipahami berkaitan dengan perintah mengucapkan kata-kata yang mudah sehingga ayat ini bagaikan menyatakan "katakanlah kepada mereka ucapan yang mudah untuk memperoleh rahmat dari Tuhanmu." 28

Terkait dengan proses komunikasi dakwah, dalam buku metode dakwah ada beberapa hal yang harus diperhatikan ketika sang da'I menggunakan qaulan maisura jika ditinjau dari karakter dan kondisi mad'u yang akan dihadapi adalah:29

a. Orang tua atau kelompok orang tua yang merasa dituakan, yang sedang menjalani kesedihan lantaran kurang bijaknya perlakuan anak terhadap orang tuanya atau kelompok yang lebih muda

b. Orang yang tergolong dizalimi hak-haknya oleh orang-orang yang lebih kuat.

c. Masyarakat yang secara sosial berada dibawah garis kemiskinan, lapisan masyarakat tersebut sangat peka dengan nasihat yang panjang, karenanya da'i harus memberikan solusi dengan membantu mereka dengan dakwah bil-hal.

5. Qaulan Karima

Qaulan karima dapat diartikan sebagai "perkataan yang mulia". Jika dikaji lebih jauh, komunikasi dakwah dengan menggunakan qaulan karima lebih ke sasaran (mad'u) dengan tingkatan umumnya lebih tua. Sehingga, pendekatan yang digunakan lebih pada pendekatan yang sifatnya pada sesuatu yang santun, lembut, dengan tingkatan dan sopan santun yang diutamakan. Dalam artian, memberikan penghormatan dan tidak menggurui dan retorika yang berapi-api. ${ }^{30}$

Terkait hal tersebut, ungkapan qaulan karima ini diidentifikasi dalam surat Al-Isra ayat 23:

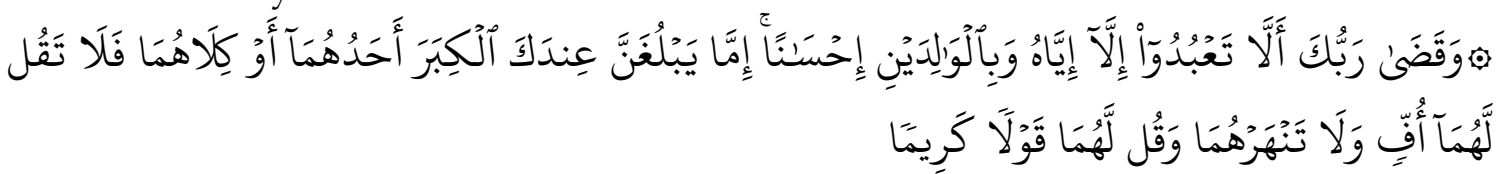

Artinya: "Dan Tuhanmu telah memerintahkan supaya kamu jangan menyembah selain dia dan hendaklah kamu berbuat baik pada ibu bapakmu dengan sebaik-baiknya, jika salah seorang di antara keduanya atau kedua-duanya sampai berumur lanjut dalam pemeliharanmu,. Maka sekali-kali janganlah kamu mengatakan kepada keduanya perkataan "ah" dan janganlah kamu membentak mereka dan ucapkanlah kepada mereka perkataan yang mulia".31

Ayat diatas menuntut agar apapun yang disampaikan kepada orangtua bukan saja yang benar dan tepat, bukan saja yang sesuai dengan adat dan kebiasaan yang baik dalam masyarakat, tetapi juga yang diiringi dengan terbaik dan yang termulia. Dan kalaupun seandainya orangtua melakukan "kesalahan" terhadap anak maka kesalahan tersebut harus dianggap tak ada atau dimaafkan (dalam arti dianggap tidak pernah ada dan terhapus dengan sendirinya), bagaimanapun juga, tidak ada orangtua yang bermaksud buruk pada anaknya.

${ }^{28}$ Wahyu Ilahi, MA. Komunikasi Dakwah, Opcit, hlm.182

${ }^{29}$ Wahyu Ilahi, MA. Komunikasi Dakwah, Ibid, hlm.183

${ }^{30}$ Wahyu Ilahi, MA. Komunikasi Dakwah, Ibid, hlm. 176

${ }^{31}$ Departemen Agama RI, Al-Qur'an dan Terjemahnya, (Kudus: Menara Kudus, 2006), hlm. 284 
Demikianlah, makna "kariman yang dipesankan kepada anak dalam menghadap orangtuanya". 32

6. Qaulan Sadidan

Qaulan sadidan dapat diartikan sebagai "pembicaraan yang benar", "jujur", "tidak bohong", "lurus", "tidak berbelit-belit". Dalam Al-Qur'an, kata qaulan sadidan terungkap sebanyak dua kali yaitu yang pertama, Allah Swt, menyuruh qaulan sadidan dalam menghadapi urusan anak yatim dan keturunanya. ${ }^{33}$

Dalam Al-Qur'an surat An-Nisa ayat 9, yaitu :

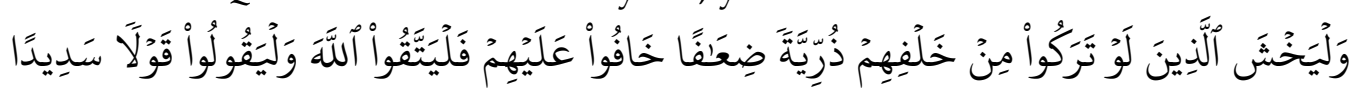

Artinya : Dan hendaklah orang-orang yang seandainya meninggalkan dibelakang mereka anak-anak yang lemah, yang mereka khawatirkan terhadap (kesejahteraan) mereka (hendaklah) mereka takut. Oleh sebab itu hendaklah mereka bertakwa kepada Allah dan hendaklah mereka mengucapkan perkataan yang benar lagi tepat".

Dalam konteks ayat diatas, sebagai tafsirannya keadaan sebagai anak-anak yatim pada hakikatnya berbeda dengan anak-anak kandung dan ini menjadikan mereka lebih peka, sehingga membutuhkan perlakuan yang lebih hati-hati dan kalimatkalimat yang lebih terpilih, bukan saja dalam segi kandungannya yang benar, tetapi juga yang tepat. Sehingga kalau memberi informasi atau menegur jangan sampai menimbulkan kekeruhan dalam hati mereka, tetapi teguran yang disampaikan hendaknya meluruskan kesalahan sekaligus membina mereka. ${ }^{34}$

Dari macam-macam qaulan yang dipaparkan diatas, model komunikasi dalam pandangan Al-Qur'an lebih menekankan pada aspek etika dan tata cara berkomunikasi yang baik. Sehingga tidak menimbulkan dampak negative saat berinterkasi pada orang lain. ${ }^{35}$ Dakwah moderasi mengedepankan komunikasi prefentif untuk meminimalisir perdebatan, konflik dan mendahulukan sifat hikmah (bijak) dalam penyampaiannya.

\section{Dakwah Moderasi di Tengah Pandemi Covid 19}

Dakwah moderasi moderasi yang dapat dilakukan oleh setiap da'i pada masa pandemi Covid 19 adalah dakwah dengan menggunakan media yang berbasis Teknologi Informasi, seperti yang marak dilakukan saat pandemi covid 19 dengan menggunakan Media Zoom Meeting, Google Meet, Webex, atau aplikasi video konfren. Hal ini dilakukan sebagai sarana mengurangi penularan wabah virus secara massif. Dakwah moderasi yang biasanya dilakukan dengan tatap muka, saat pandemi Covid 19 dilakukan menggunakan video konfren dari rumah masingmasing. Dengan demikian dakwah moderasi yang dilakukan masih bisa tetap berjalan, meskipun tidak secara langsung bertemu dengan mad'u.

\section{Simpulan}

Hemat penulis Dakwah moderasi pada masa pandemi covid 19 dapat dilakukan dengan menggunakan media teknologi informasi berupa video konferensi diantaranya, Zoom Meeting, Google Meeting, Webex, Skype. Dakwah moderasi yang mendahulukan sifat toleran, bijak (hikmah), dakwah yang inklusif bukan

32 Wahyu Ilahi, MA. Komunikasi Dakwah, Op.cit, hlm. 177

${ }^{33}$ Wahyu Ilahi, MA.Komunikasi Dakwah, Ibid, hlm. 187

${ }^{34}$ Departemen Agama RI, Al-Qur'an dan Terjemahnya, (Kudus: Menara Kudus, 2006), hlm. 78

35 Wahyu Ilahi, MA. Komunikasi Dakwah, Op.cit, hlm. 188 
dakwah yang eksklusif, mengedepankan konsep komunikasi dalam Al-Qur'an seperti Qoulan Baligha, Qoulan Ma'rufa, Qoulan Layyina, Qoulan Syadida, Qoulan Maysura. Dakwah moderasi disampaikan dengan metode dakwah sesuai QS. An Nahl : 125 yaitu, Bil Hikmah, Mauidhoh Hasanah dan Mujadalah.

\section{Referensi}

Aziz, Moh. Ali, Ilmu Dakwah Edisi Revisi, (Jakarta: Kencana, 2004)

Departemen Agama RI, Al-Qur'an dan Terjemahnya, (Kudus: Menara Kudus, 2006)

Jalaluddin Rahmat, Etika Komunikasi Prespektif Religi, (Makalah seminar: Jakarta, 1996)

Jalaluddin Rahmat, Islam Aktual, (Mizan,1996)

Kementerian Agama, Moderasi Beragama, (Jakarta : Kementerian Agama RI, 2019)

M. Munir, Metode Dakwah, Cet. Ke-3, (Jakarta: Kencana, 2009)

M. Munir, S.Ag, MA. Metode Dakwah, (Jakarta:Kencana Prenada Media Group,2009)

Samsul Munir Amin, Ilmu Dakwah, (Jakarta: Hamzah, 2009)

Saputra, Pengantar Ilmu Dakwah, (Jakarta: PT Raja Grafindo Persada, 2011)

Wahyu Ilahi, MA. Komunikasi Dakwah, (Bandung: PT.Remaja Rosdakarya,2010) 